\title{
Models for the active site in galactose oxidase: Structure, spectra and redox of copper(II) complexes of certain phenolate ligands
}

\author{
MATHRUBOOTHAM VAIDYANATHAN and \\ MALLAYAN PALANIANDAVAR* \\ Department of Chemistry, Bharathidasan University, Tiruchirappalli 620 024, \\ India \\ e-mail: palani@bdu.ernet.in
}

\begin{abstract}
Galactose oxidase (GOase) is a fungal enzyme which is unusual among metalloenzymes in appearing to catalyse the two electron oxidation of primary alcohols to aldehydes and $\mathrm{H}_{2} \mathrm{O}_{2}$. The crystal structure of the enzyme reveals that the coordination geometry of mononuclear copper(II) ion is square pyramidal, with two histidine imidazoles, a tyrosinate, and either $\mathrm{H}_{2} \mathrm{O}(p \mathrm{H} 7 \cdot 0)$ or acetate (from buffer, $p \mathrm{H} \mathrm{4.5)}$ in the equatorial sites and a tyrosinate ligand weakly bound in the axial position. This paper summarizes the results of our studies on the structure, spectral and redox properties of certain novel models for the active site of the inactive form of GOase. The monophenolato $\mathrm{Cu}(\mathrm{II})$ complexes of the type $[\mathrm{Cu}(\mathrm{L} 1) \mathrm{X}][\mathrm{H}(\mathrm{L} 1)=2$ (bis(pyrid-2-ylmethyl)aminomethyl)-4-nitrophenol and $\mathrm{X}^{-}=\mathrm{Cl}^{-} \mathbf{1}, \mathrm{NCS}^{-} \mathbf{2}, \mathrm{CH}_{3} \mathrm{COO}^{-}$ 3, $\mathrm{ClO}_{4}^{-}$4] reveal a distorted square pyramidal geometry around $\mathrm{Cu}$ (II) with an unusual axial coordination of phenolate moiety. The coordination geometry of $\mathbf{3}$ is reminiscent of the active site of GOase with an axial phenolate and equatorial $\mathrm{CH}_{3} \mathrm{COO}^{-}$ligands. All the present complexes exhibit several electronic and EPR spectral features which are also similar to the enzyme. Further, to establish the structural and spectroscopic consequences of the coordination of two tyrosinates in GOase enzyme, we studied the monomeric copper(II) complexes containing two phenolates and imidazole/pyridine donors as closer structural models for GOase. N,Ndimethylethylenediamine and $\mathrm{N}, \mathrm{N}^{\prime}$-dimethylethylenediamine have been used as starting materials to obtain a variety of 2,4-disubstituted phenolate ligands. The $\mathrm{X}$-ray crystal structures of the complexes $[\mathrm{Cu}(\mathrm{L} 5)(\mathrm{py})],(\mathbf{8})\left[\mathrm{H}_{2}(\mathrm{~L} 5)=\mathrm{N}, \mathrm{N}\right.$-dimethyl- $\mathrm{N}^{\prime}, \mathrm{N}^{\prime}-$ bis(2-hydroxy-4-nitrobenzyl) ethylenediamine, py = pyridine $]$ and $\left[\mathrm{Cu}(\mathrm{L} 8)\left(\mathrm{H}_{2} \mathrm{O}\right)\right]$ (11), $\quad\left[\mathrm{H}_{2}(\mathrm{~L} 8)=\mathrm{N}, \mathrm{N}^{\prime}\right.$-dimethyl-N,N'-bis(2-hydroxy-4-nitrobenzyl)ethylenediamine $]$ reveal distorted square pyramidal geometries around $\mathrm{Cu}$ (II) with the axial tertiary amine nitrogen and water coordination respectively. Interestingly, for the latter complex there are two different molecules present in the same unit cell containing the methyl groups of the ethylenediamine fragment $c i s$ to each other in one molecule and trans to each other in the other. The ligand field and EPR spectra of the model complexes reveal square-based geometries even in solution. The electrochemical and chemical means of generating novel radical species of the model complexes, analogous to the active form of the enzyme is presently under investigation.
\end{abstract}

Keywords. $\mathrm{Cu}(\mathrm{II})$ phenolate complexes; X-ray structures; electronic spectra; electron paramagnetic resonance spectra; redox behaviour; galactose oxidase.

\section{Introduction}

Galactose oxidase (GOase) is a fungal enzyme that catalyses the two-electron oxidation of galactose and a number of primary alcohols by molecular oxygen yielding the corresponding aldehyde and $\mathrm{H}_{2} \mathrm{O}_{2}{ }^{1-3}$.

*For correspondence 


$$
\mathrm{RCH}_{2} \mathrm{OH}+\mathrm{O}_{2} \rightarrow \mathrm{RCH}=\mathrm{O}+\mathrm{H}_{2} \mathrm{O}_{2} \text {. }
$$

The active site of the enzyme consists of a mononuclear copper ion in a square pyramidal coordination geometry. The copper ion is coordinated to two histidine residues (His-496 and His-581), a tyrosinate residue (Tyr-272), and a water molecule (at $p \mathrm{H} \mathrm{7 \cdot 0)}$ ) or acetate (from buffer at $p \mathrm{H} \mathrm{4.5)}$ in the equatorial plane and to a further tyrosinate residue (Tyr$495)$ in the apical position at a longer distance $(2.65 \AA)$ from copper $^{4}$ (scheme 1 ). A unique feature of this active site embodies the modification of the tyrosinate residue located in the equatorial plane by a covalent linkage to the sulphur atom of a nearby cysteine residue. The mononuclear copper site can be present in three redox forms viz. fully oxidized, fully reduced and an inactive form. The fully oxidized and reduced forms were identified as the catalytically active ones. However, extensive spectroscopic studies have unambiguously established that the fully oxidized active site consists of a copper(II) antiferromagnetically coupled to a tyrosyl radical, which has been determined to be derived from the equatorially bound ortho-S-modified Tyr-272. Further, many features of the chemistry of inactive GOase is altered by the interaction of the enzyme with exogenous anions.

To understand the structural and spectroscopic consequences of phenolate donors in this enzyme, we initiated a study of monomeric copper(II) complexes containing monoand bis-phenolate and pyridine donors as structural models for GOase. In a series of recent papers we have reported ${ }^{5-7}$ the X-ray crystal structures and spectroscopic and electrochemical studies of the mononuclear complexes $[\mathrm{Cu}(\mathrm{L} 1) \mathrm{X}][\mathrm{H}(\mathrm{L} 1)=2-($ bis $($ pyrid2-ylmethyl)aminomethyl)-4-nitrophenol; $\mathrm{X}^{-}=\mathrm{Cl}^{-} \mathbf{1}, \mathrm{NCS}^{-} \mathbf{2}, \mathrm{CH}_{3} \mathrm{COO}^{-}$3, and $\mathrm{ClO}_{4}^{-}$4] (scheme 2). These complexes have been isolated to duplicate the anion interaction and the unique spectral changes accompanying it. The acetate complex has been prepared with an aim to simulate the basal interactions found at the copper site of the enzyme ${ }^{7}$. The

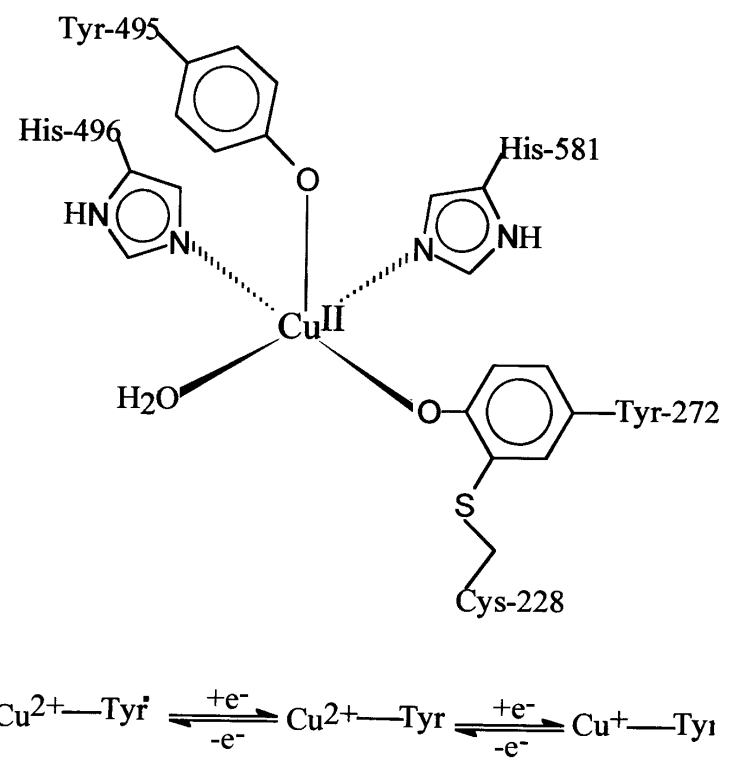

Scheme 1. Schematic view of the active site of GOase in the inactive state at $p \mathrm{H} 7 \cdot 0^{4}$ and the three oxidation levels of GOase. 


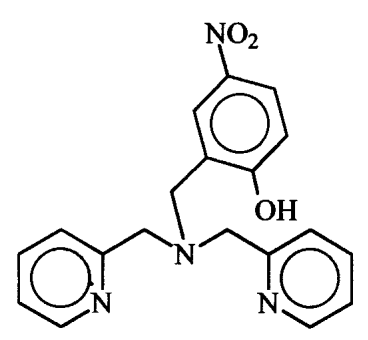

H(L1)<smiles>O=[N+]([O-])c1ccc(O)c(CN(Cc2ccccn2)Cc2cc([N+](=O)[O-])ccc2O)c1</smiles>

$\mathrm{H}_{2}$ (L3)<smiles>[R2]c1cc([R])c(O)c(CN(CCCN(C)C)Cc2cc([R2])cc([R])c2O)c1</smiles>

$\begin{array}{lll}\mathbf{R}_{\mathbf{1}} & \mathbf{R}_{\mathbf{2}} & \\ \mathrm{H} & \mathrm{NO}_{2} & \mathrm{H}_{2}(\mathrm{~L} 5) \\ \mathrm{CH}_{3} & \mathrm{CH}_{3} & \mathrm{H}_{2}(\mathrm{~L} 6) \\ t-\mathrm{Bu} & t-\mathrm{Bu} & \mathrm{H}_{2}(\mathrm{~L} 7)\end{array}$<smiles>O=[N+]([O-])c1ccc(O)c(CN(Cc2nc3ccccc3[nH]2)Cc2nc3ccccc3[nH]2)c1</smiles>

H(L2)<smiles>O=[N+]([O-])c1ccc(O)c(CN(Cc2nc3ccccc3[nH]2)Cc2cc([N+](=O)[O-])ccc2O)c1</smiles>

$\mathrm{H}_{2}$ (L4)

Scheme 2. Ligands employed in the study.

chloride complex is the first one to contain an unusually axially coordinated phenolate and mimic the axial $\mathrm{Cu}$ (II)-phenolate bond in the inactive GOase. Like the chloride complex, the other complexes also contain the novel axially coordinated phenolate ion. On the other hand, the phenolate group is coordinated equatorially rather than axially in the analogous model complexes reported by Fenton et $a l^{9,10}$. A few other model systems that contain axial phenolate group have been also reported ${ }^{10}$. Whittaker et al investigated the structures of several mononuclear copper(II) complexes derived from the simple 
polyamine $\mathrm{N}, \mathrm{N}, \mathrm{N}^{\prime}, \mathrm{N}^{\prime \prime}, \mathrm{N}^{\prime \prime}$-pentamethyldiethylenetriamine and $p$-cresol, 2-methylsulfanyl or 2-methyl-sulfinyl-p-cresol in order to closely mimic the cystein-modified tyrosinate in the protein species ${ }^{11}$. Much progress towards understanding the nature of the active sites of the enzymes has been now made by the characterization and reactions of several $\mathrm{Cu}$ (II)-phenoxyl radical species ${ }^{12-20}$. Certain model complexes that mimic both the structural as well as catalytic aspects of the active site of this enzyme was recently reported by Stack et $a l^{21,22}$ and another catalytically active model by Wieghardt $e t a l^{23}$ has also been studied. However, appropriate and closely mimicking mononuclear model complexes and their derived metal-phenoxyl radical species stabilized by ligands are still lacking.

The catalytically active form of GOase contains one axial $\mathrm{Cu}$ (II)-tyrosine and one equatorial $\mathrm{Cu}$ (II)-tyrosyl radical. In order to incorporate two phenolates into copper(II) geometry so as to more closely mimic the GOase enzyme, we have also designed a series of tetradentate linear and tripodal ligands (scheme 2) containing two phenolates that would favour monomeric square pyramidal $\mathrm{Cu}$ (II) geometries. Such complexes would provide equatorial phenolate donor(s) for oxidation to a phenoxyl radical as in the enzyme. The bulky electron donating $t$-butyl/methyl groups are introduced instead of the S-alkyl group in the enzyme to prevent dimerization of complexes and to form the monomeric species. Summarized in this review is our progress towards understanding the various structural aspects of the GOase enzyme by studying the structure, spectra and redox behaviour of the novel $\mathrm{Cu}(\mathrm{II})$ mono- and bis-phenolato complexes.

\section{Experimental}

The synthesis and characterization of the $\mathrm{Cu}(\mathrm{II})$ complexes (1-7) of the ligands $\mathrm{H}(\mathrm{L} 1)$ $\mathrm{H}_{2}(\mathrm{~L} 4)$ and the experimental methods employed for them have been described previously ${ }^{5-7}$. The synthesis of the ligands $\mathrm{H}_{2}(\mathrm{~L} 5)-\mathrm{H}_{2}(\mathrm{~L} 10)$ and their $\mathrm{Cu}(\mathrm{II})$ complexes (8-13) are reported elsewhere ${ }^{24}$.

\section{Results and discussion}

The very flexible tripodal ligand $\mathrm{H}(\mathrm{L} 1)$ has been predicted ${ }^{6}$ to form complexes with structures exhibiting a range of conformations. The para substituted phenolic moiety in the ligand resembles the amino acid tyrosine ${ }^{25}$ and the pyridine (py) nitrogens mimic the histidine imidazole in the active site of GOase. The ligand $\mathrm{H}(\mathrm{L} 1)$ with two pyridine nitrogens, one imine nitrogen and one phenolic oxygen has been designed in order to mimic the histidine and phenolic moieties respectively, in the enzyme GOase (scheme 1). The catalytically active form of GOase contains one axial $\mathrm{Cu}(\mathrm{II})$-tyrosine and an equatorial $\mathrm{Cu}$ (II)-tyrosyl radical. The diamines $\mathrm{N}, \mathrm{N}$-dimethylethylenediamine and $\mathrm{N}, \mathrm{N}^{\prime}$ dimethylethylenediamine have been used as the starting materials and the hydrogen atoms on nitrogen donors of the amines have been replaced with various 2,4-disubstituted phenolate moieties to generate the ligands $\mathrm{H}_{2}(\mathrm{~L} 5)-\mathrm{H}_{2}(\mathrm{~L} 10)$ for the present study of models with two coordinated phenolates (scheme 2).

\subsection{Structures of $\mathrm{Cu}(\mathrm{II})$ complexes}

The ORTEP plots of $\mathbf{1 - 4 , 8}$ and $\mathbf{1 1}$ are depicted in figures $1 \mathrm{a}-\mathrm{d}$ and $2 \mathrm{a}-\mathrm{b}$ respectively with the atom numbering scheme. The selected bond lengths and bond angles are given in 
table 1 and the copper(II) coordination geometries are compared in figure 3 . In the crystal structures of $[\mathrm{Cu}(\mathrm{L} 1) \mathrm{X}]$ complexes $\left[\mathrm{X}^{-}=\mathrm{Cl}^{-} \mathbf{1}, \mathrm{NCS}^{-} 2, \mathrm{CH}_{3} \mathrm{COO}^{-} 3\right]$ the copper ion is coordinated to the two pyridine and tertiary amine nitrogens of the ligand $\mathrm{H}(\mathrm{L} 1)$ and the chloride, $\mathrm{SCN}^{-}$nitrogen and acetate oxygen respectively in the equatorial plane and the phenolate oxygen of $\mathrm{H}(\mathrm{L} 1)$ in the axial position. The geometries around copper(II) in the complexes 1-3 are best described as square pyramidal with a small trigonal component as revealed by the trigonal index ${ }^{18} \mathrm{t}$ of $0 \cdot 16,0 \cdot 24$ and 0.29 respectively for $\mathbf{1}, \mathbf{2}$ and $3[t=(b-a) / 60$, for perfect square pyramidal and for trigonal bipyramidal geometries the $\mathrm{t}$ values are zero and unity respectively]. Copper is displaced $0.223 \AA, 0.208 \AA$ and $0 \cdot 167 \AA$ above the $\mathrm{CuN}_{3} \mathrm{Cl}, \mathrm{CuN}_{4}$ and $\mathrm{CuN}_{3} \mathrm{O}$ coordination planes respectively and towards the axially coordinated phenolate oxygen. It is interesting to note that the axial phenolate oxygen is hydrogen-bonded to $\mathrm{NH}_{4}{ }^{+}$ion which in turn is hydrogen-bonded to the nitrogen atom of uncoordinated $\mathrm{NCS}^{-}$ion $\mathbf{2}$ and to the oxygen atom of methanol in $\mathbf{3}$.

The complex cation of $\mathbf{4}$ is a centrosymmetric dimer composed of two distorted square-based $\mathrm{Cu}$ (II) coordination spheres. Each copper(II) ion is coordinated to a tertiary amine and two pyridine nitrogens of $\mathrm{H}(\mathrm{L} 1)$ and a phenolate from the second coordination sphere, in the basal plane and the square based geometry is completed by the axial coordination of the first phenolate to form an unsymmetrically bridged $\mathrm{Cu}_{2} \mathrm{O}_{2}$ core. The two parts of the dimer are trans to each other and the $\mathrm{Cu}$... Cu distance is $3.09 \AA$. The trigonality index $(\mathrm{t}=0.48)$ for the perchlorate is higher than those for the $\mathrm{Cl}^{-}, \mathrm{SCN}^{-}$and $\mathrm{CH}_{3} \mathrm{COO}^{-}$complexes, suggesting an increase in trigonality and hence steric constraints at the copper on dimerization. Thus copper is displaced $0 \cdot 143 \AA$ away from the $\mathrm{CuN}_{3} \mathrm{O}$

Table 1. Comparison of selected bond lengths $(\AA)$ and bond angles (deg) of model complexes.

\begin{tabular}{|c|c|c|c|c|c|c|c|}
\hline & \multicolumn{4}{|c|}{$[\mathrm{Cu}(\mathrm{L} 1) \mathrm{X}]$} & \multirow{3}{*}{$\frac{[\mathrm{Cu}(\mathrm{L} 2)(\mathrm{py})]}{\mathbf{5}}$} & \multicolumn{2}{|c|}{$\left[\mathrm{Cu}(\mathrm{L} 5)\left(\mathrm{H}_{2} \mathrm{O}\right)\right]$} \\
\hline & \multirow{2}{*}{$\begin{array}{c}\mathrm{Cl}^{-} \\
1\end{array}$} & \multirow{2}{*}{$\begin{array}{c}\mathrm{NCS}^{-} \\
\mathbf{2}\end{array}$} & \multirow{2}{*}{$\begin{array}{c}\mathrm{CH}_{3} \mathrm{COO}^{-} \\
\mathbf{3}\end{array}$} & \multirow{2}{*}{$\mathrm{ClO}_{4}^{-}$} & & & 8 \\
\hline & & & & & & A & B \\
\hline $\mathrm{Cu}-\mathrm{N}(\mathrm{py})$ & $1 \cdot 986(1)$ & $1.990(2)$ & $1.995(4)$ & $2 \cdot 025(4)$ & $2 \cdot 092(2)$ & & \\
\hline $\mathrm{Cu}-\mathrm{N}(\mathrm{py})$ & $1.997(1)$ & $1.987(2)$ & $1.992(4)$ & $1.993(4)$ & & & \\
\hline $\mathrm{Cu}-\mathrm{N}(\mathrm{am})$. & $2 \cdot 060(1)$ & $2 \cdot 044(2)$ & $2 \cdot 052(4)$ & $2 \cdot 014(3)$ & $2 \cdot 083(2)$ & $2 \cdot 040(11)$ & $2 \cdot 058(12)$ \\
\hline $\mathrm{Cu}-\mathrm{N}(\mathrm{am})$. & & & & & & $2 \cdot 042(13)$ & $2 \cdot 015(10)$ \\
\hline $\begin{array}{l}\mathrm{Cu}-\mathrm{N}(\mathrm{am} .) \\
\text { (diMe-subs.) }\end{array}$ & & & & & $2 \cdot 283(2)$ & & \\
\hline $\begin{array}{l}\mathrm{Cu}-\mathrm{O}(\mathrm{ax} .) \\
\text { phe/ } \mathrm{H}_{2} \mathrm{O}\end{array}$ & $2 \cdot 268(2)$ & $2 \cdot 186(2)$ & $2 \cdot 200(3)$ & $2 \cdot 174(3)$ & & $2 \cdot 367(9)$ & $2 \cdot 402(8)$ \\
\hline $\mathrm{Cu}-\mathrm{O} 1$ (eq) & & & & & $1 \cdot 919(2)$ & $1 \cdot 966(10)$ & $1.936(10)$ \\
\hline $\mathrm{Cu}-\mathrm{O} 2(\mathrm{eq})$ & & & & & $1 \cdot 948(2)$ & $1 \cdot 931(11)$ & $1.923(10)$ \\
\hline $\begin{array}{l}\mathrm{Cu}-\mathrm{Cl} / \\
\mathrm{N}^{\prime}(\mathrm{NCS}) /\end{array}$ & $2 \cdot 256(1)$ & $1 \cdot 947(2)$ & $1.931(3)$ & $1 \cdot 947(2)$ & & & \\
\hline $\mathrm{O}(\mathrm{ac}.) / \mathrm{O}(\mathrm{ph})$. & & & & & & & \\
\hline $\begin{array}{l}\text { Dev. of } \\
\text { Cu from eq. } \\
\text { plane }\end{array}$ & $-0 \cdot 226$ & $+0 \cdot 208$ & $+0 \cdot 163$ & $-0 \cdot 143$ & $+0 \cdot 152$ & $-0 \cdot 153$ & $+0 \cdot 166$ \\
\hline t & $0 \cdot 16$ & $0 \cdot 24$ & $0 \cdot 28$ & 0.48 & $0 \cdot 28$ & $0 \cdot 13$ & $0 \cdot 15$ \\
\hline
\end{tabular}

Abbreviations: ac-acetate; am-amine; ph-phenolate; ax. - axial; dev. - deviation; eq. - equatorial; py - pyridyl; subs. - substituted. 

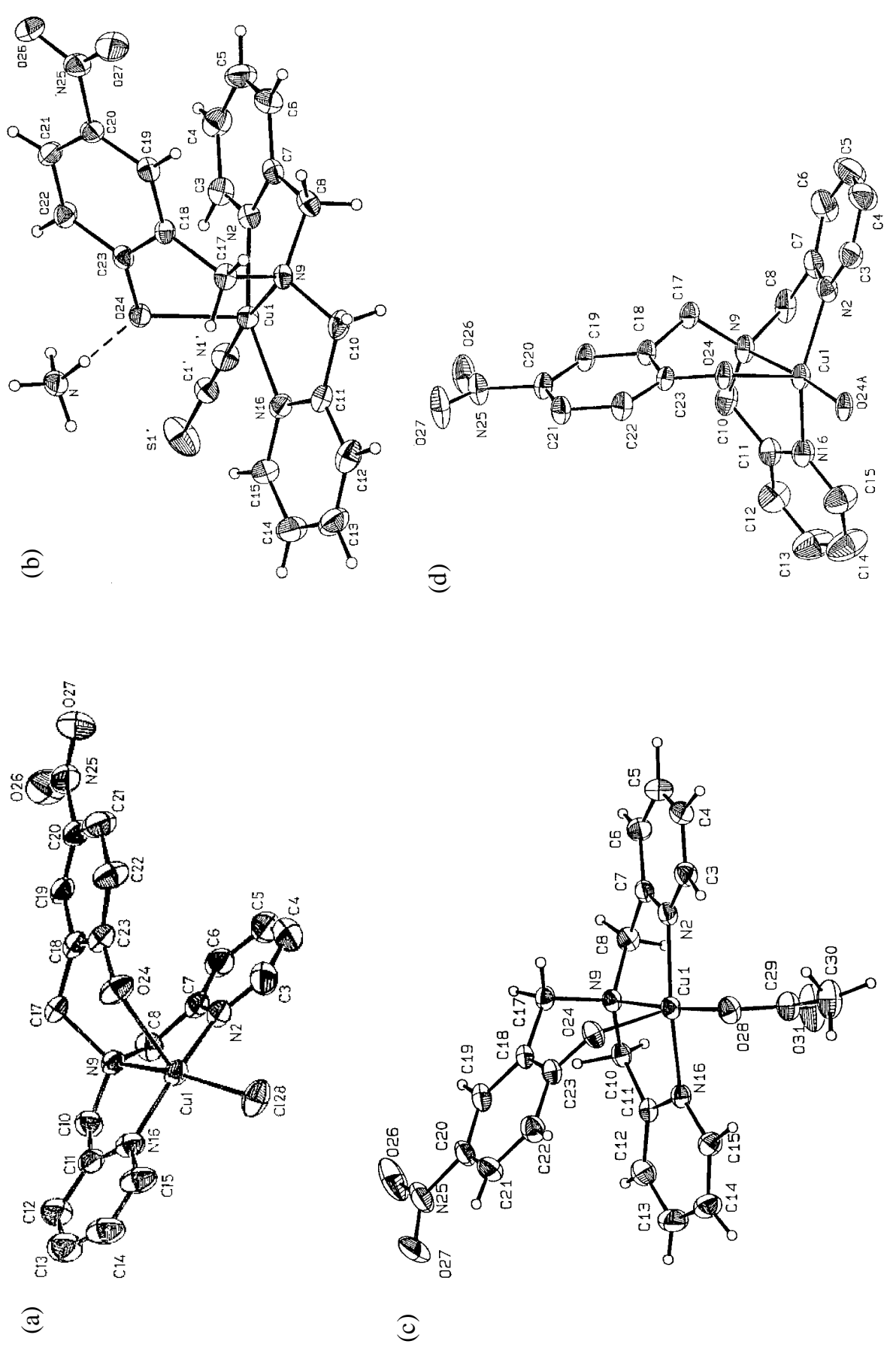

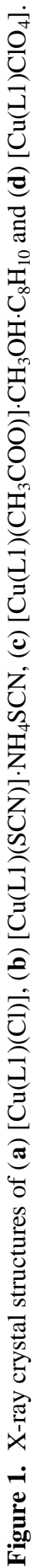




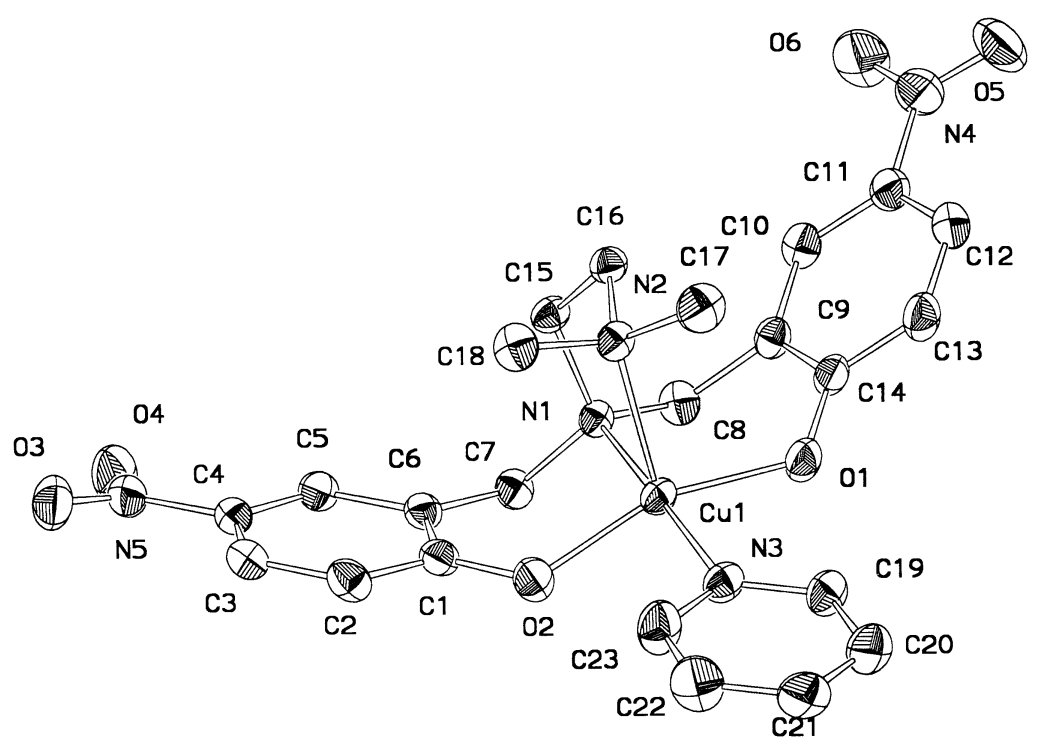

b

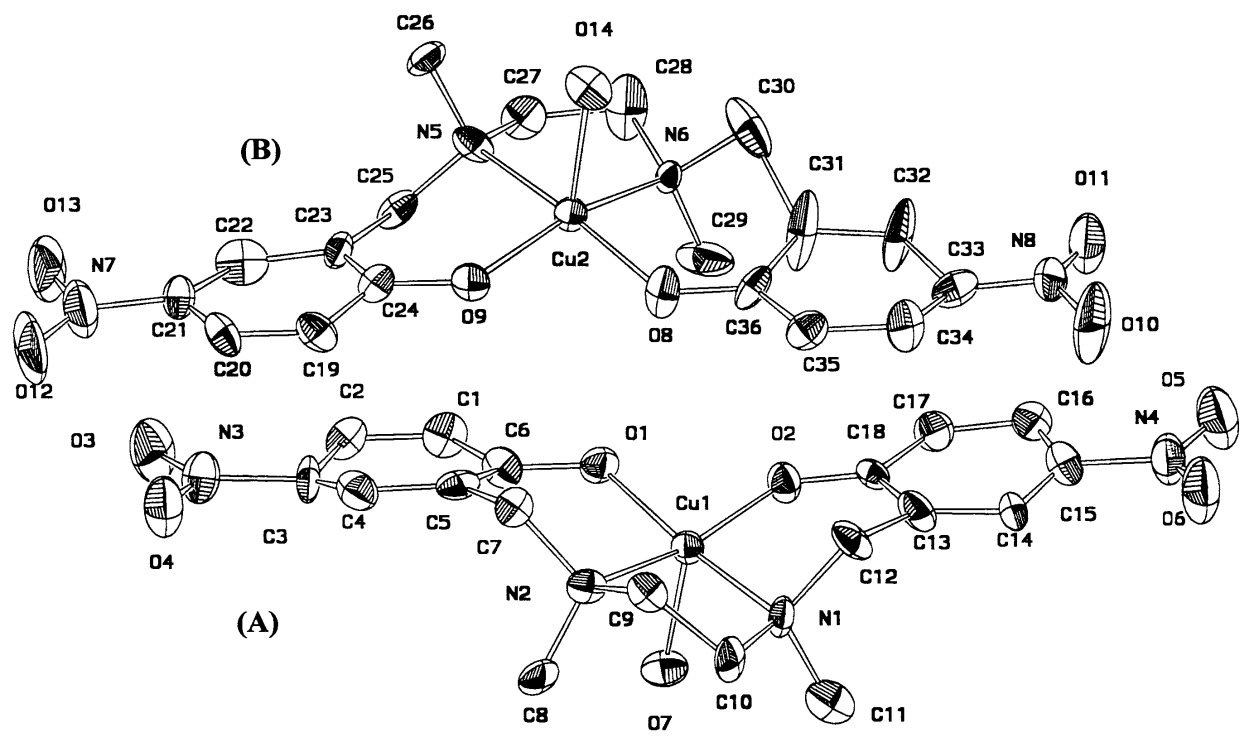

Figure 2. X-ray crystal structures of (a) $[\mathrm{Cu}(\mathrm{L} 5)(\mathrm{py})]$ and $(\mathbf{b})\left[\mathrm{Cu}(\mathrm{L} 8)\left(\mathrm{H}_{2} \mathrm{O}\right)\right]$.

coordination plane but opposite to the axial $\mathrm{Cu}$ (II)-phenolate bond, unlike in the other three complexes. The present structure is different from the above monomeric $[\mathrm{Cu}(\mathrm{L} 1) \mathrm{X}]$ complexes in that it is dimeric, but is similar to them in that the $\mathrm{Cu}$ (II)-phenolate bond is axial. The dimerization appears to be due to the inability of the perchlorate ion to coordinate strongly in the equatorial position, which leads to the coordinated phenolate group in the neighbouring molecule to default ${ }^{19,20}$ to the equatorial position in the first molecule. 
The axial $\mathrm{Cu}(\mathrm{II})$-phenolate bonds in the present mono- and binuclear complexes are unusual and this is in remarkable contrast to the equatorial $\mathrm{Cu}(\mathrm{II})$-phenolate bond observed in the analogous complex $\left[\mathrm{Cu}(\mathrm{L}) \mathrm{N}_{3}\right][\mathrm{HL}=\mathrm{N}, \mathrm{N}-$ bis (pyrid-2-ylethyl)-2methylaminophenol $]^{21}$ and in the homologues $[\mathrm{Cu}(\mathrm{L}) \mathrm{X}][\mathrm{HL}=2$ - $[$ bis (pyrid-2-

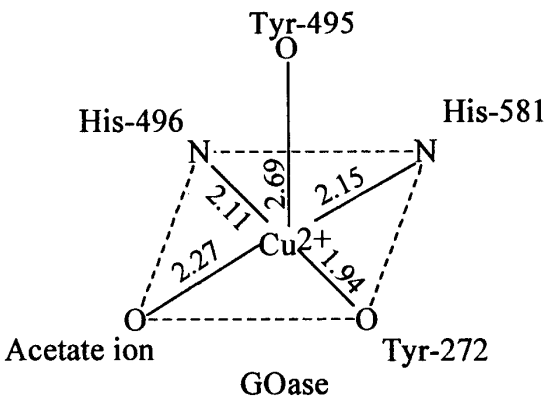

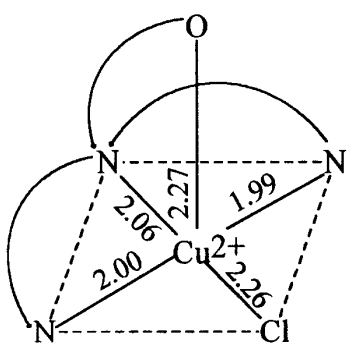
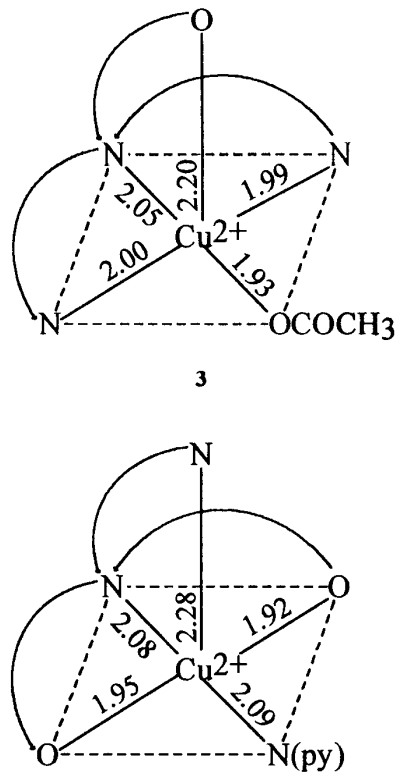

8
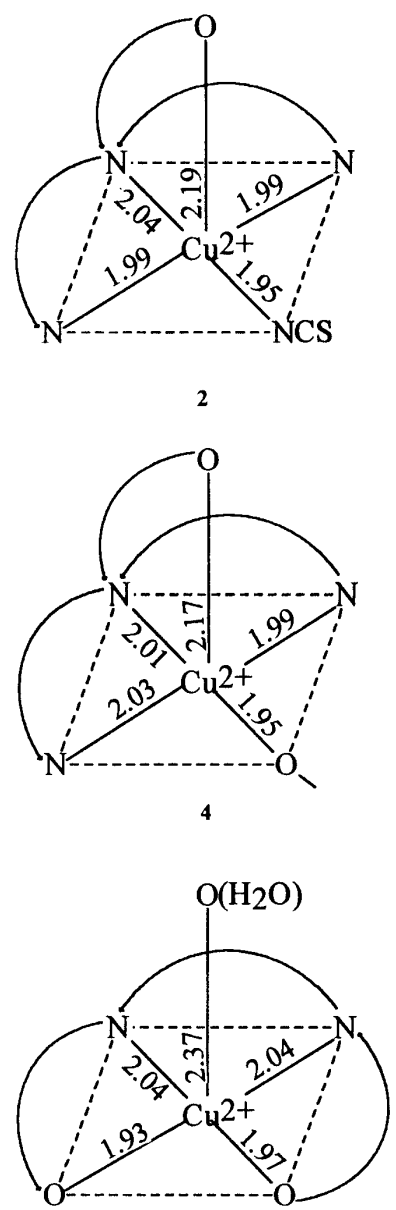

11 (Cis)

Figure 3. Comparison of copper(II) coordination environments of GOase and the present model complexes. 
ylethyl)aminomethyl]-4-nitrophenol, $\left.\mathrm{X}^{-}=\mathrm{SCN}^{-}, \mathrm{CH}_{3} \mathrm{COO}^{-}\right]$, all of which contain a 6,6,6-membered chelate ring sequence at the copper atom whereas the present complexes possess a 5,5,6-chelate ring sequence. It is therefore suggested that the nature of chelate rings formed and the consequent steric factors involved are responsible for the axial coordination of $p$-nitrophenolate ion in the present complexes; the steric constraint at copper increases on replacing the 6-membered chelate rings by 5-membered ones. Further, the stronger coordination of the 5-membered chelate rings in the equatorial plane of the present compounds is implied by the equatorial $\mathrm{Cu}-\mathrm{N}_{\mathrm{py}}$ bonds [1.986(2)$2 \cdot 025(5) \AA$ ] which are shorter than those of the respective homologues $\left[\mathrm{SCN}^{-}, 2 \cdot 026(5)\right.$; $\mathrm{CH}_{3} \mathrm{COO}^{-}, 2 \cdot 046(3)$ and $\left.\mathrm{ClO}_{4}^{-}, 1 \cdot 983(15) \AA\right]$. Thus in the present compounds the extension of one of the tripodal arms (6-membered ring) and hence its large flexibility ${ }^{22}$ favours the stronger phenolate donor to occupy the axial position (against Jahn-Teller distortion) and in the homologues the stronger phenolate donor defaults to the equatorial position, as expected ${ }^{19,20}$. As a consequence of the axial phenolate coordination both the pyridine nitrogen donors in the present complexes occupy trans-equatorial sites, whereas one of the pyridines in the homologues and in the azide complex ${ }^{21}$ takes up the axial position. It is interesting to note that the axial $\mathrm{Cu}$ (II)-phenolate bond $(\mathrm{Cu}-\mathrm{O}, 2 \cdot 174 \AA$ ) is longer than the equatorial one (1.947 $\AA$ ), because of the Jahn-Teller effect.

The coordination plane of the complex $[\mathrm{Cu}(\mathrm{L} 5)(\mathrm{py})] \mathbf{8}$ of the tripodal ligand $\mathrm{H}_{2}(\mathrm{~L} 5)$ with two phenolic hydroxyl groups is comprised of two coordinated phenolates, one amine nitrogen and an exogenous pyridine nitrogen with the dimethyl substituted amine nitrogen axially coordinating. The phenolates and the exogenous pyridine ligand are cisequatorially coordinated. The geometry around $\mathrm{Cu}$ (II) is best described as trigonal bipyramidal distorted square based pyramidal (TBDSBP) as revealed by the trigonal index $\mathrm{t}$ of 0.28 . The axial $\mathrm{Cu}-\mathrm{N}_{\text {amine }}$ bond length in the present complex is $2.283 \AA$ which is longer than the equatorial $\mathrm{Cu}-\mathrm{N}_{\text {amine }}$ bond distance of $2.075 \AA$ in an analogous complex. The occupation of the dimethyl amine nitrogen in the axial position at a longer distance is due to the stronger coordination of the two phenolates in the equatorial plane and the Jahn-Teller effect. The copper(II) is displaced $0 \cdot 152 \AA$ above the $\mathrm{CuN}_{2} \mathrm{O}_{2}$ coordination plane toward the axial amine nitrogen. In the crystal structure of $\left[\mathrm{Cu}(\mathrm{L} 8)\left(\mathrm{H}_{2} \mathrm{O}\right)\right] \mathbf{1 1}$ there are two different molecules present in the same unit cell. The coordination plane in both the molecules is comprised of two phenolates and two amine nitrogens of L8 and an exogenous water molecule is coordinated axially. The bond lengths and bond angles are different for the two molecules. Interestingly, one molecule (A) has the methyl groups of the ethylenediamine fragment cis to each other and in the other molecule (B) these methyl groups are trans to each other. The axial $\mathrm{Cu}-\mathrm{O}\left(\mathrm{H}_{2} \mathrm{O}\right)$ bond distance in molecule B (Cu2-O14, 2.402 $\AA$ ) is longer than that in A $(\mathrm{Cu} 1-\mathrm{O} 7$, $2 \cdot 367 \AA$ ) due to steric hindrance from the cis-methyl groups in A. In both molecules $\mathrm{Cu}(\mathrm{II})$ is in a square pyramidal environment with slight difference in the value of trigonality index, $\mathrm{t}(\mathrm{A}, 0 \cdot 13 ; \mathrm{B}, 0 \cdot 15)$. The complex $\left[\mathrm{Cu}(\mathrm{L} 8)\left(\mathrm{H}_{2} \mathrm{O}\right)\right] \mathbf{1 1}$ is more planar than the other tripodal complexes 1-4 and 8, as evident from the values of trigonality index, obviously because the ligand $\mathrm{H}_{2}(\mathrm{~L} 8)$ is a linear tetradentate ligand, suitable for imposing square planar geometry, while $\mathrm{H}(\mathrm{L} 1)$ and $\mathrm{H}_{2}(\mathrm{~L} 5)$ are tripodal tetradentate ligands which tend to impose a trigonal bipyramidal geometry around $\mathrm{Cu}(\mathrm{II})$. The different degrees of distortions in the coordination geometries of the present complexes may be traced to the plasticity effect of copper(II). The presence of two tyrosinate ligations in GOase is modelled by the present compounds 4, 8 and $\mathbf{1 1}$ in having two 
Table 2. Spectral and redox properties of model complexes.

\begin{tabular}{|c|c|c|c|c|c|}
\hline & \multirow{3}{*}{$\begin{array}{l}\text { Electronic spectra } \\
\mathrm{I}_{\max }\left(\mathrm{e}, \mathrm{M}^{-1} \mathrm{~cm}^{-1}\right)\end{array}$} & \multirow[b]{3}{*}{ EPR spectra ${ }^{a}$} & \multicolumn{3}{|c|}{$\operatorname{Redox}^{\mathrm{e}}$} \\
\hline & & & \multirow{2}{*}{$\begin{array}{l}\text { Supporting } \\
\text { electrolyte }\end{array}$} & \multicolumn{2}{|c|}{$E_{1 / 2}(\mathrm{~V})$} \\
\hline & & & & $\mathrm{CV}$ & DPV \\
\hline$[\mathrm{Cu}(\mathrm{L} 1) \mathrm{Cl}], \mathbf{1}$ & $\begin{array}{l}\text { DMF } \\
714(240) \\
980(160) \\
407(36200) \\
485(345) \mathrm{sh} \\
\mathrm{CH}_{3} \mathrm{CN} \\
719(97) \\
398(18570)\end{array}$ & $\begin{array}{l}\mathrm{MeOH} \\
\mathrm{g}_{\|} 2 \cdot 217 \\
\mathrm{~A}_{\|} 173 \\
\mathrm{CH}_{3} \mathrm{CN} \\
\mathrm{g}_{\|} 2 \cdot 218 \\
\mathrm{~A}_{\|} 174\end{array}$ & $\mathrm{MeOH} / \mathrm{NEt}_{4} \mathrm{BF}_{4}$ & -0.53 & $-0 \cdot 56$ \\
\hline $\begin{array}{l}{[\mathrm{Cu}(\mathrm{L} 1) \mathrm{SCN}] \cdot} \\
\mathrm{NH}_{4} \mathrm{SCN}, \mathbf{2}\end{array}$ & $\begin{array}{l}\mathrm{MeOH} \\
667(225) \\
383(26100) \\
\mathrm{CH}_{3} \mathrm{CN} \\
862(136) \\
714(121) \\
392(20210)\end{array}$ & $\begin{array}{l}\mathrm{MeOH} \\
\mathrm{g}_{\|} 2 \cdot 225 \\
\mathrm{~A}_{\|} 185\end{array}$ & $\mathrm{CH}_{3} \mathrm{CN} / \mathrm{THAP}^{\mathrm{f}}$ & $-0 \cdot 77$ & $\begin{array}{l}-0 \cdot 72 \\
-0.90\end{array}$ \\
\hline $\begin{array}{l}{\left[\mathrm{Cu}(\mathrm{L} 1) \mathrm{CH}_{3} \mathrm{COO}\right] \cdot} \\
\mathrm{CH}_{3} \mathrm{OH} \cdot \mathrm{C}_{8} \mathrm{H}_{10}, \mathbf{3}\end{array}$ & $\begin{array}{l}\mathrm{H}_{2} \mathrm{O} \\
662(135) \\
392(20440) \\
\mathrm{CH}_{3} \mathrm{CN} \\
690(112) \\
397(23310)\end{array}$ & $\begin{array}{l}\mathrm{MeOH}^{\mathrm{b}} \\
\mathrm{g}_{\|} 2 \cdot 242 \\
\mathrm{~A}_{\|} 183 \\
\mathrm{DMF} \\
\mathrm{g}_{\|} 2 \cdot 228 \\
\mathrm{~A}_{\|} 177\end{array}$ & DMF/THAP & $-0 \cdot 85$ & $-0 \cdot 85$ \\
\hline$\left[\mathrm{Cu}(\mathrm{L} 1) \mathrm{ClO}_{4}\right], 4$ & $\begin{array}{l}\mathrm{DMF}^{\mathrm{c}} \\
741(140) \\
848(150) \\
391(16400) \\
\mathrm{CH}_{3} \mathrm{CN}^{\mathrm{c}} \\
800(160) \\
351(15370)\end{array}$ & $\begin{array}{l}\text { DMF }^{\mathrm{d}} \\
\mathrm{g}_{\|} 2 \cdot 276 \\
\mathrm{~A}_{\|} 185\end{array}$ & $\mathrm{CH}_{3} \mathrm{CN} / \mathrm{THAP}$ & $\begin{array}{l}-0 \cdot 64 \\
-1 \cdot 02^{\mathrm{g}}\end{array}$ & $\begin{array}{l}-0 \cdot 58 \\
-1 \cdot 16\end{array}$ \\
\hline$[\mathrm{Cu}(\mathrm{L} 2)(\mathrm{py})], \mathbf{8}$ & $\begin{array}{l}\text { DMF } \\
774(216) \\
394(38500)\end{array}$ & $\begin{array}{l}\text { DMF } \\
\mathrm{g}_{\|} 2 \cdot 242 \\
\mathrm{~A}_{\|} 157\end{array}$ & DMF/TBAP & $-0.97^{\mathrm{h}}$ & $-1 \cdot 00$ \\
\hline$\left[\mathrm{Cu}(\mathrm{L} 3)\left(\mathrm{H}_{2} \mathrm{O}\right)\right], 9$ & $\begin{array}{l}\mathrm{MeOH} \\
734(100) \\
464(1915)\end{array}$ & $\begin{array}{l}\mathrm{MeOH} \\
\mathrm{g}_{\|} 2 \cdot 299 \\
\mathrm{~A}_{\|} 152\end{array}$ & MeOH/TBAP & $\begin{array}{l}-0 \cdot 59^{\mathrm{g}} \\
-0 \cdot 92^{\mathrm{i}}\end{array}$ & $-0 \cdot 88$ \\
\hline$\left[\mathrm{Cu}(\mathrm{L} 4)\left(\mathrm{H}_{2} \mathrm{O}\right), \mathbf{1 0}\right.$ & $\begin{array}{l}\mathrm{MeOH} \\
637(180) \\
392(960)\end{array}$ & $\begin{array}{l}\mathrm{MeOH} \\
\mathrm{g}_{\|} 2 \cdot 244 \\
\mathrm{~A}_{\|} 189\end{array}$ & MeOH/THAP & $\begin{array}{l}-0 \cdot 47^{\mathrm{g}} \\
-0 \cdot 94^{\mathrm{i}}\end{array}$ & $-1 \cdot 03$ \\
\hline$\left[\mathrm{Cu}(\mathrm{L} 5)\left(\mathrm{H}_{2} \mathrm{O}\right), \mathbf{1 1}\right.$ & $\begin{array}{l}\mathrm{CH}_{3} \mathrm{CN} \\
639(415) \\
393(46290)\end{array}$ & $\begin{array}{l}\mathrm{CH}_{3} \mathrm{CN} \\
\mathrm{g}_{\|} 2 \cdot 234 \\
\mathrm{~A}_{\|} 188\end{array}$ & $\mathrm{CH}_{3} \mathrm{CN} / \mathrm{TBAP}$ & -0.99 & -0.99 \\
\hline$\left[\mathrm{Cu}(\mathrm{L} 6)\left(\mathrm{H}_{2} \mathrm{O}\right)\right], \mathbf{1 2}$ & $\begin{array}{l}\mathrm{MeOH} \\
597(555) \\
429(1890)\end{array}$ & $\begin{array}{l}\mathrm{MeOH} \\
\mathrm{g}_{\|} 2 \cdot 229 \\
\mathrm{~A}_{\|} 182\end{array}$ & $\mathrm{CH}_{2} \mathrm{Cl}_{2} / \mathrm{TBAP}$ & $-0.63^{\mathrm{i}}$ & -0.61 \\
\hline$\left[\mathrm{Cu}(\mathrm{L} 7)\left(\mathrm{H}_{2} \mathrm{O}\right)\right], 13$ & $\begin{array}{l}\mathrm{CH}_{2} \mathrm{Cl}_{2} \\
647(1370) \\
448(1960)\end{array}$ & $\begin{array}{l}\mathrm{CH}_{2} \mathrm{Cl}_{2} \\
\mathrm{~g}_{\|} 2 \cdot 230 \\
\mathrm{~A}_{\|} 177\end{array}$ & $\mathrm{CH}_{2} \mathrm{Cl}_{2} / \mathrm{TBAB}$ & $-0 \cdot 98^{\mathrm{i}}$ & $-0 \cdot 84$ \\
\hline
\end{tabular}

${ }^{\mathrm{a}} \mathrm{A} \|$ in $10^{-4} \mathrm{~cm}^{-1}$. ${ }^{\mathrm{b}}$ Five N-superhyperfine lines observed. ${ }^{\mathrm{c}}$ Concentration based on monomer. ${ }^{\mathrm{d}} \mathrm{Half}-$ field signal $\left(\mathrm{DM}^{\mathrm{s}}= \pm 2\right)$ at 1650 gauss. ${ }^{\mathrm{e}} \mathrm{S}$ can rate: $50 \mathrm{mV} / \mathrm{s}$. ${ }^{\mathrm{f}}$ The complex was washed with water and used for electrochemistry. ${ }^{\mathrm{g}}$ Additional cathodic peak. ${ }^{\mathrm{h}}$ Half peak potential $\left(E_{\mathrm{p} / 2}\right)$ quoted. ${ }^{\mathrm{i}}$ Peak potential $\left(E_{\mathrm{p}}\right)$ quoted. 
phenolates in symmetrically inequivalent positions as evident from their crystal structures, even though the distinct long axial and short equatorial phenolate bonding pattern for the square pyramidal copper centre in the enzyme is not exactly replicated.

\subsection{Spectral properties}

The spectral properties (table 2) of tripodal monophenolato [Cu(L1)X] complexes $\mathbf{1 - 4}$ are found to be anion and solvent dependent. Thus the reflectance and solution spectral properties of the monomeric complexes 1-3 are similar to each other, but are significantly different from those of the dimeric complex 4, which is expected ${ }^{23,24}$ of the difference in their coordination geometries. The polycrystalline complex $\mathbf{4}$ displays two ligand field (LF) bands and a rhombic EPR spectrum, which is consistent with its trigonally distorted $\mathrm{Cu}$ (II) geometry; the $\mathrm{DM}_{\mathrm{s}}= \pm 2$ signal around $1650 \mathrm{G}$ in the EPR spectrum is characteristic of its dimeric structure. In contrast to $\mathbf{4}$, the polycrystalline monomeric complexes display only one visible band in the reflectance spectra and either rhombic or isotropic or axial features in their EPR spectra. The relatively high values of $I_{\max }(630$ $800 \mathrm{~nm}$ ) observed in the reflectance spectra of all these complexes are consistent with the observed displacement ${ }^{25,26}$ of $\mathrm{Cu}$ (II) from the $\mathrm{N}_{4}$ plane towards the axial phenolate, anion $^{27}$ or oxygen $^{28}$ coordination and presence of trigonal component ${ }^{29}$ in the coordination geometries.

In DMF and $\mathrm{MeOH}$ solutions all the monomeric complexes 1-3 exhibit only one LF band. However, in acetonitrile solution the thiocyanate complex 2 displays two LF bands. This unique behaviour of $\mathbf{2}$ is relevant to that of GOase enzyme ${ }^{30}$ on adding $\mathrm{SCN}^{-}$. In contrast, the homologous ${ }^{31}$ thiocyanate and other monomeric complexes with equatorial phenolates display only one LF band. This suggests that the axial rather than the cisequatorial phenolate facilitates $\mathrm{SCN}^{-}$to coordinate strongly. The cryogenic solution EPR spectra of all the complexes including 4 are axial suggesting the presence of a $d_{x^{2}-y_{2}}$ ground state in $\mathrm{Cu}$ (II) located in square-based geometries ${ }^{32}$. The $\mathrm{DM}_{\mathrm{s}}= \pm 2$ signal of 4 observed in the solid state is not discernible in solution suggesting the partial dissociation of the dimeric complex to yield solvated monomeric species. The $\mathrm{g}_{\|}$values lie in the range 2.22-2.28 suggesting the presence of a $\mathrm{CuN}_{2} \mathrm{O}_{2}$ or $\mathrm{CuN}_{3} \mathrm{O}$ chromophore ${ }^{19,33}$ in solution also, with the dimeric complex 4 having the highest $\mathrm{g}_{\|}\left[\mathrm{Cl}^{-}<\mathrm{NCS}^{-}<\mathrm{CH}_{3} \mathrm{COO}^{-}\right.$ $\left.<\mathrm{ClO}_{4}\left(\mathrm{CH}_{3} \mathrm{CN}\right)\right]$ and $\mathrm{I}_{\max }$ values compared to monomeric complexes; these values are consistent with the increased trigonal distortion in $\mathbf{4}$ and/or the anion ${ }^{27} /$ solvent $^{34}$ coordination in monomeric complexes, discussed above. Interestingly, the EPR parameters $\left(\mathrm{g}_{\|,}, 2 \cdot 22-2 \cdot 28 ; \mathrm{A}_{\|}, 173-189 \times 10^{-4} \mathrm{~cm}^{-1}\right)$ of monomeric complexes are close to those for ferrocyanide-reduced GOase ${ }^{35}$ at $p \mathrm{H} 4.5\left(\mathrm{~g}_{\|}, 2 \cdot 28 ; \mathrm{A}_{\|}, 181 \times 10^{-4} \mathrm{~cm}^{-1}\right)$.

The monomeric complexes show an intense band in the range 390-400 nm assignable $^{36}$ to $\mathrm{Cu}(\mathrm{II})\left(d_{x^{2}-y^{2}}\right)$-to-(axial)phenolate (pp) MLCT transition. This is in sharp contrast to the slightly higher energy and less intense phenolate(equatorial)-to- $\mathrm{Cu}$ (II) LMCT band observed for their homologues ${ }^{31}$. Interestingly, the dimeric complex 4 exhibits an intense band around $354 \mathrm{~nm}\left(\Theta \mathrm{Cu}, 15370 \mathrm{M}^{-1} \mathrm{~cm}^{-1}\right)$ with a shoulder around $400 \mathrm{~nm}\left(\Theta \mathrm{Cu}, \sim 7000 \mathrm{M}^{-1} \mathrm{~cm}^{-1}\right)$, while the analogous dimeric complexes ${ }^{37}$ with equatorially ligated phenolates exhibit only one less intense band in the range 400$460 \mathrm{~nm}\left(\mathrm{e} / \mathrm{Cu}, 4000 \mathrm{M}^{-1} \mathrm{~cm}^{-1}\right)$. So we assign the high energy band in 4 to $\mathrm{Cu}$ (II)-to(axial)phenolate MLCT transition and the shoulder to phenolate (equatorial)-to-Cu(II) LMCT transition. This assignment is in line with the following observations from a study of the effect of dilution on 4 and its reaction with anions $\left(\mathrm{Cl}^{-}, \mathrm{SCN}^{-}, \mathrm{CH}_{3} \mathrm{COO}^{-}\right)$which 
led to the formation of two monomeric $[\mathrm{Cu}(\mathrm{L} 1) \mathrm{X}]$ complex molecules. The MLCT band rather than the ligand field band of $\mathbf{4}$ shows remarkable concentration dependence; the $354 \mathrm{~nm}\left(\Theta / \mathrm{Cu}, 15370 \mathrm{M}^{-1} \mathrm{~cm}^{-1}\right)$ band is gradually shifted on dilution to $\sim 390 \mathrm{~nm}(\Theta \mathrm{Cu}$, $17350 \mathrm{M}^{-1} \mathrm{~cm}^{-1}$ ) as a broad feature. This clearly reveals that at low concentrations the dimer tends to dissociate into solvated monomer with axial phenolate coordination, which is consistent with the cryogenic EPR spectrum of $\mathbf{4}$. The solubility of $\mathbf{3}$ in water $(p \mathrm{H} 6 \cdot 8)$ enabled the study of sensitivity of the complex to protons. In the spectrophotometric titration of the complex 3 with $\mathrm{H}^{+} / \mathrm{OH}^{-}$, dramatic and reversible $p \mathrm{H}$ dependent changes occur in the CT and LF regions, but not in the EPR spectra. The titrable group in the complex is the axially coordinated phenolate, suggesting the ability of axial phenolate ion to dissociate from metal ion to act as a good proton acceptor without affecting the equatorial coordination.

All the bis-phenolato $\mathrm{Cu}(\mathrm{II})$ complexes of the ligands $\mathrm{H}_{2}(\mathrm{~L} 5)-\mathrm{H}_{2}(\mathrm{~L} 10)$ show a broad ligand field band in the $\mathrm{I}_{\max }$ range of $600-775 \mathrm{~nm}\left(\mathrm{e} \sim 100-1400 \mathrm{M}^{-1} \mathrm{~cm}^{-1}\right)$ suggesting the presence of square based geometries around $\mathrm{Cu}(\mathrm{II})$. The lower ligand field energies of the complexes of the ligands $\mathrm{H}_{2}(\mathrm{~L} 5)-\mathrm{H}_{2}(\mathrm{~L} 7)$ are obviously on account of the higher trigonality imposed by the tripodal ligands as evident from the crystal structure of one of these complexes viz $[\mathrm{Cu}(\mathrm{L} 5)(\mathrm{py})]$. All the complexes are deeply coloured due to the absorption spectral feature with the $I_{\max }$ in the range 390-460 nm (e 1000$46000 \mathrm{M}^{-1} \mathrm{~cm}^{-1}$ ) which is assigned to $\mathrm{PhO}^{-} \rightarrow \mathrm{Cu}$ (II) ligand-to-metal charge transfer $(\mathrm{LMCT}) /$ metal-to-ligand charge transfer transition. In the solid state EPR spectra of the complexes 9 and $\mathbf{1 0}$ are observed a broad $\Delta M_{\mathrm{s}}= \pm 2$ signal around $1600 \mathrm{G}$, which is characteristic of a dimeric structure for them; however, the signal is not discernible in frozen solution spectra. Similar dimeric structures have been observed for analogous complexes of tripodal ligands containing two phenolate groups ${ }^{10}$. The frozen solution $\mathrm{X}$-band EPR spectra of all the complexes exhibit axial signals which are consistent with $d_{x^{2}-y^{2}}$ ground state $\left(\mathrm{g}_{\|}>\mathrm{g}_{\perp}>2 \cdot 0, \mathrm{~A}_{\|}, 150-180 \times 10^{-4} \mathrm{~cm}^{-1}\right)$ for $\mathrm{Cu}(\mathrm{II})$. The $\mathrm{g}_{\|}$values lie in the range 2.23-2.29 consistent with presence of $\mathrm{CuO}_{2} \mathrm{~N}_{2}$ or $\mathrm{CuO}_{3} \mathrm{~N}$ chromophores. Further, the $g_{\|}$and $A_{\|}$values of most of the complexes lie in the region for $\mathrm{CuO}_{2} \mathrm{~N}_{2}$ chromophores in the $\mathrm{g}_{\|} \mathrm{vs}_{\|} \mathrm{plot}^{33}$ and are interestingly close to those of GOase ${ }^{19}$.

\subsection{Electrochemical properties}

While the dimeric complex 4 of the ligand $\mathrm{H}(\mathrm{L} 1)$ exhibits two consecutive one electron transfer, the monomeric complexes $\mathbf{1 - 3}$ of the ligand $\mathrm{H}(\mathrm{L} 1)$ with monophenolate coordination exhibit one electron transfer. The electrochemical behaviour $\left(i_{\mathrm{pa}} / i_{\mathrm{pc}}, 0 \cdot 9, E_{1 / 2}\right.$, $-0.844 \mathrm{~V}$ and $\Delta E_{\mathrm{p}}, 120 \mathrm{mV}$ of the acetate complex 3 at a Pt electrode in DMF/THAP; plot of $i_{\mathrm{pc}}$ vs $v^{1 / 2}$ is linear and passes through the origin) suggests that the $\mathrm{Cu}(\mathrm{II}) / \mathrm{Cu}(\mathrm{I})$ redox process tends to become quasireversible and diffusion controlled. The $E_{12}$ values decrease in the order $\mathrm{Cl}^{-}>\mathrm{CH}_{3} \mathrm{CN}\left(\mathrm{ClO}_{4}^{-}\right)>\mathrm{SCN}^{-}>\mathrm{CH}_{3} \mathrm{COO}^{-}$suggesting the involvement of anions in coordination. All the bis-phenolato complexes of the ligands $\mathrm{H}_{2}(\mathrm{~L} 5)-\mathrm{H}_{2}(\mathrm{~L} 10)$ show irreversible $\mathrm{Cu}(\mathrm{II}) / \mathrm{Cu}(\mathrm{I})$ one electron redox process and the value of redox potentials $(-0.61-1.03 \mathrm{~V})$ are typical of $\mathrm{Cu}(\mathrm{II})$ complexes with two coordinated phenolates (figure 4). Additional daughter cathodic peaks at -0.59 and $-0.47 \mathrm{~V}$ respectively for the complexes $\mathbf{9}$ and $\mathbf{1 0}$ indicate the existence of the complexes as dimeric species in equilibrium with their monomers in solution, which is in line with the above EPR spectral studies. The oxidation waves observed (figure 4) for these complexes 
in the peak potential range of $0 \cdot 32-0.99 \mathrm{~V}$ corresponds to the formation of phenoxyl radical-copper(II) species.

\section{Conclusions and relevance of axial phenolate coordination and bis-phenolate coordination to GOase enzyme}

Tripodal ligands are well known for their tendency to impose a trigonal bipyramidal geometry $^{29,38}$ on $\mathrm{Cu}(\mathrm{II})$. However, they do not exhibit any restraint ${ }^{5,6,39,40}$ on this geometry to rearrange to a square-based geometry. Thus the geometry around $\mathrm{Cu}$ (II) in the present tripodal ligand complexes is found to be square-based, both in the solid state and in the solution. Further, the different degrees of distortion observed in the geometries may be traced to the 'plasticity effect' (flexible geometry) in copper(II) ${ }^{27}$, which is the final consequence of Jahn-Teller effect.

The novel presence of $\mathrm{Cu}$-phenolate bond in the axial position, the consequent location of pyridine nitrogens in the trans-equatorial sites in all the $[\mathrm{Cu}(\mathrm{L} 1) \mathrm{X}]$ complexes, and the coordination of the acetate ion in the equatorial site in $\mathbf{3}$ are interesting structural features which are remarkably similar to those present in the inactive GOase enzyme. The mixed equatorial/axial phenolate ligation in the dimer is an additional noteworthy structural feature, relevant to the two equatorial/axial tyrosines coordinated to $\mathrm{Cu}$ (II) in the active site of the native enzyme. Further, the replacement of a weakly ligated ligand by a strongly coordinating ligand in the equatorial position appears to decrease the electronic interaction between $\mathrm{Cu}$ (II) and the axially coordinated phenolate ligand and hence lead to the observed elongation of the axial $\mathrm{Cu}-\mathrm{O}$ bond. Thus the axial $\mathrm{Cu}(\mathrm{II})$-phenolate bond length varies dramatically with the change in equatorially sited anions in the order, $\mathrm{Cl}^{-}>\mathrm{CH}_{3} \mathrm{COO}^{-}>\mathrm{SCN}^{-}>\mathrm{PhO}^{-}\left(\mathrm{ClO}_{4}^{-}\right)$, showing the stronger

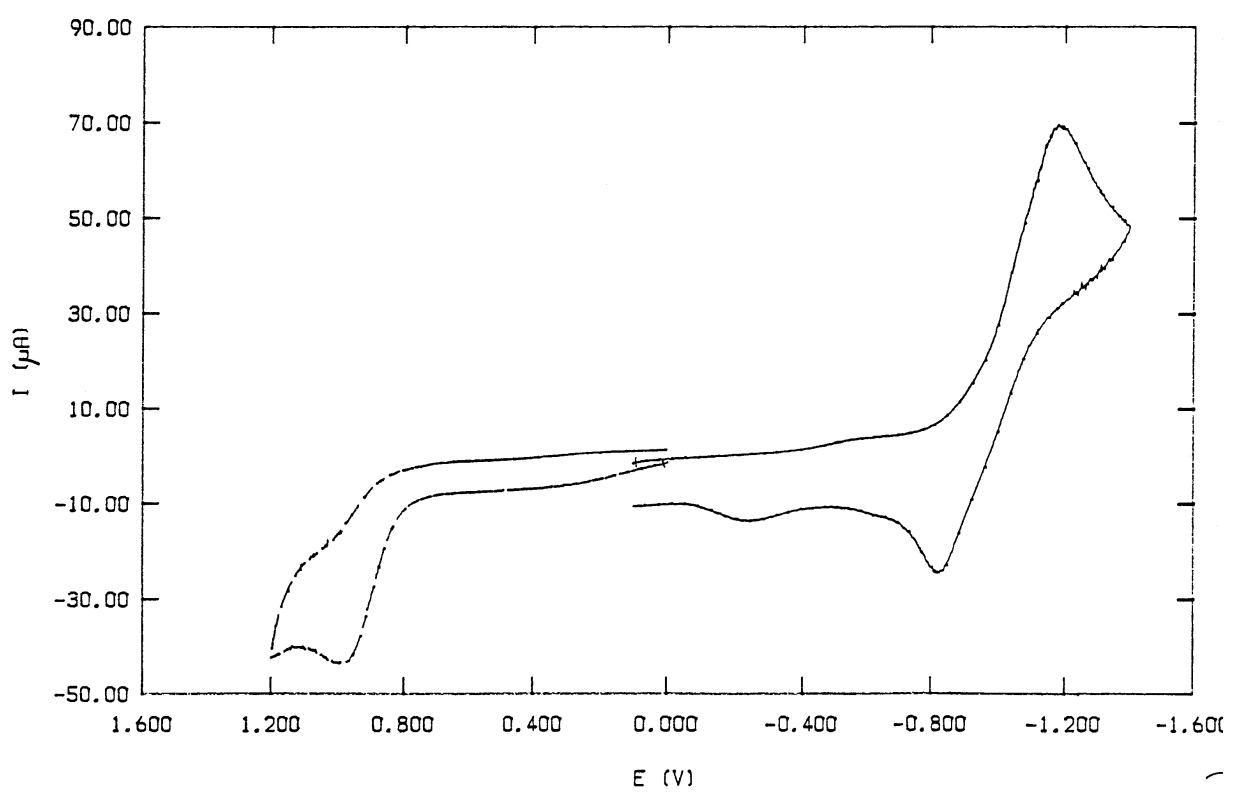

Figure 4. The cyclic voltammogram of $0.001 \mathrm{M}$ complex 11 in $\mathrm{CH}_{3} \mathrm{CN}$ at $25^{\circ} \mathrm{C}$ at $0.05 \mathrm{~V} / \mathrm{s}$ scan rate. 

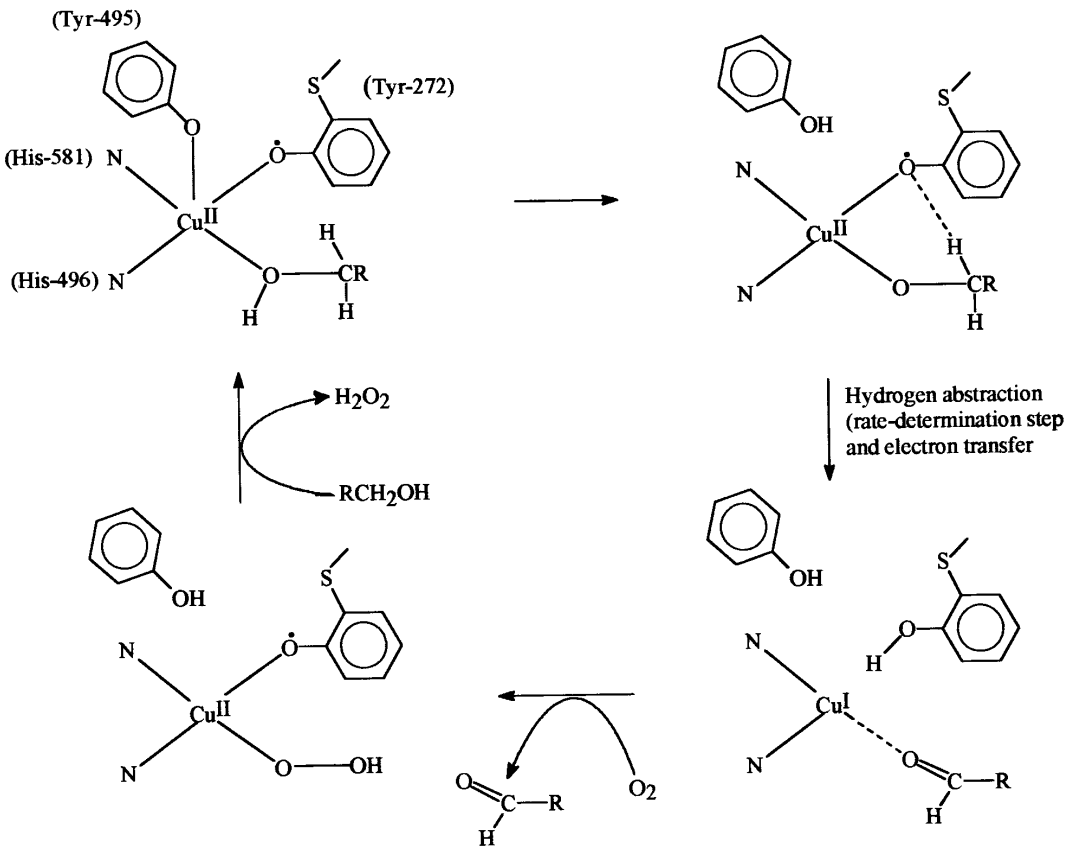

Scheme 3. Proposed mechanism of catalysis by GOase ${ }^{43}$.

coordination of chloride ion to $\mathrm{Cu}$ (II). The same order is exhibited by the $\mathrm{Cu}$ (II)- $\mathrm{N}_{\mathrm{py}}$ axial bond lengths for the homologous compounds. These observations represent a clear manifestation of the Jahn-Teller effect in the copper(II) located in the square pyramidal geometry. A similar effect of exogenous anion binding on the spectral, and possibly on the catalytic properties observed ${ }^{10,41}$ for the biological complex would be traced to the interplay of coordination chemistry of anion binding through the Jahn-Teller effect in the square-based 'Type II' or 'normal' active site geometry. Moreover, the interesting observation of the axially coordinated phenolate, which is hydrogen-bonded ${ }^{8}$ to an additional donor atom as observed in $\mathbf{2}$ or to $\mathrm{CH}_{3} \mathrm{OH}$ as in $\mathbf{3}$, provides significant insight into the proposed ${ }^{42}$ mechanism of alcohol oxidation by GOase and supports the acid/base roles predicted for the axial phenolate ligand in catalysis (scheme 3). The binding of alcohol substrate to copper through its hydroxyl group at the labile equatorial position of the active site would enhance the acidity of the enzyme-substrate complex, facilitating the ionization of hydroxyl group of the substrate, with proton delivered to the endogenous base viz the axial tyrosinate. Thus, all the $[\mathrm{Cu}(\mathrm{L} 1) \mathrm{X}]$ complexes display novel structural features which are remarkably very similar to those of inactive GOase enzyme. The presence of two tyrosinate ligations in GOase is modelled in the present complexes 8-13 of the ligands $\mathrm{H}_{2}(\mathrm{~L} 5)-\mathrm{H}_{2}(\mathrm{~L} 10)$ by incorporating two phenolates in symmetrically inequivalent positions, even though the distinct long axial and short equatorial phenolate bonding pattern for the square pyramidal copper centre in the enzyme is not exactly replicated. Appropriate ortho and para substituents like nitro, methyl and $t$-butyl groups at the phenolate rings as in the ligands $\mathrm{H}_{2}(\mathrm{~L} 5)-\mathrm{H}_{2}(\mathrm{~L} 10)$ are found to stabilise the copper(II)-phenoxyl radical species. 
The electronic and EPR spectral and electrochemical properties of the $[\mathrm{Cu}(\mathrm{L} 1) \mathrm{X}]$ complexes with axial $\mathrm{Cu}$ (II)-phenolate bond are remarkably anion dependent and the spectral properties of these complexes and those of the ligands $\mathrm{H}_{2}(\mathrm{~L} 5)-\mathrm{H}_{2}(\mathrm{~L} 10)$ are amazingly similar to those of inactive GOase enzyme as discussed above. Further, the observation of sensitivity of the $\mathrm{Cu}$ (II)-phenolate bond to $p \mathrm{H}$ and modulation of acidity by metal interaction are amazingly similar to those observed for glyoxal oxidase ${ }^{10}$ and GOase $^{41}$. Thus the present monomeric complexes with axial $\mathrm{Cu}$ (II)-phenolate bond, particularly the acetate and the dimeric complex containing both axial and equatorial $\mathrm{Cu}$ (II)-phenolate bonds and the complexes with two equatorial phenolate ligands $\mathrm{H}_{2}(\mathrm{~L} 5)$ $\mathrm{H}_{2}$ (L10) appear to be promising synthetic systems to probe not only the structural and spectral features but also the relationship between the bonding properties of an equatorially coordinated exogenous ligand and its effect on the catalytic activity of the metallobiosite in GOase catalysis. Work is progressing in our laboratory to investigate the oxidation chemistry of these complexes by using chemical and electrochemical methods.

\section{Acknowledgement}

We thank the Department of Science and Technology, New Delhi for financial support and University Grants Commission (UGC), New Delhi for a Fellowship to MV. We thank Prof CNR Rao and Dr G U Kulkarni, Jawaharlal Nehru Centre for Advanced Scientific Research, Bangalore for providing X-ray diffraction facility for one of the crystals and Regional Sophisticated Instrumentation Centre, Indian Institute of Technology, Chennai for collecting the data for the other crystals and also for EPR facilities.

\section{References}

1. Whittaker M M and Whittaker J W 1988 J. Biol. Chem. 2636074

2. Whittaker M M, Chuang Y-Y and Whittaker J W 1993 J. Am. Chem. Soc. 11510029

3. Klinman J P 1996 Chem. Rev. 962541

4. Ito N, Philips S E V, Stevenns C, Ogel Z B, McPherson M J, Keen G N, Yadav K D S and Knowles P F 1991 Nature (London) 35087

5. Uma R, Viswanathan R, Palaniandavar M, Lakshminarayanan M 1992 J. Chem. Soc., Dalton Trans. 3563

6. Uma R, Viswanathan R, Palaniandavar M, Lakshminarayanan M 1994 J. Chem. Soc., Dalton Trans. 1219

7. Vaidyanathan M, Viswanathan R, Palaniandavar M, Balasubramanian T, Prabhaharan P and Muthiah T P 1998 Inorg. Chem. 376418

8. Halfen J A, Young V G Jr and Tolman W B 1996 Angew. Chem., Int. Ed. Engl. 351687

9. Halfen J A, Jazdzewski B A, Mahapatra M, Berreau LM, Wilkinson E C, Que L Jr and Tolman W B 1977 J. Am. Chem. Soc. 1198217

10. Whittaker J W, Duncan W R and Whittaker J W 1996 Inorg. Chem. 35382

11. Sokolowski A, Leutbecher H, Weyhermüller T, Schnepf R, Bothe E, Bill E, Hildebrandt P and Wieghardt K 1997 J. Biol. Inorg. Chem. 2444

12. Zurita D, Gautier-Luneau I, Menage S, Pierre J-L and Saint-Aman E 1997 J. Biol. Inorg. Chem. 246

13. Itoh S, Takayama S, Arakawa R, Furuta A, Komatsu M, Ishida A, Takamuku S and Fukuzumi S 1997 Inorg. Chem. 361407

14. Müller J, Weyhermüller T, Bill E, Hildebrandt P, Ould-Moussa L, Glaser T and Wieghardt K 1998 Angew. Chem., Int. Ed. Engl. 37616

15. Wang Y and Stack T D P 1996 J. Am. Chem. Soc. 11813097

16. Vaidyanathan M and Palaniandavar M 1999 Inorg. Chem. (submitted) 
17. Van Landschoot R C, Van Hest J A M and Reedijk J 1983 Inorg. Chim. Acta 7289

18. Addison A W, Rao T N, Reedijk J, Van Rijn J and Vershcoor G C 1984 J. Chem. Soc., Dalton Trans. 1349

19. Addison A W, Burke P J, Henrick K, Nageswara Rao T and Sinn E 1983 Inorg. Chem. 223645

20. Palaniandavar M, Pandiyan T, Lakshminarayanan M and Manohar H 1995 J. Chem. Soc., Dalton Trans. 455

21. Karlin K D, Cohen B I, Hayes J C, Farooq A and Zubieta J 1987 Inorg. Chem. 26147

22. Alilou E E, Amadei E, Giorgi M, Pierrot M and Reglier M 1993 J. Chem. Soc., Dalton Trans. 549

23. Harrison D, Kennedy D and Hathaway B J 1981 Inorg. Nucl. Chem. Lett. 17087

24. Tyagi S and Hathaway B J 1981 J. Chem. Soc., Dalton Trans. 2029

25. Hoskins B F and Whillans F D 1972 Coord. Chem. Rev. 9365

26. Addison A W, Carpenter M, Lau L K-M and Wicholas M 1978 Inorg. Chem. 171545

27. Hathaway B J 1987 In Comprehensive coordination chemistry (eds) G Wilkinson, R G Gillard and J A McCleverty (Oxford: Pergamon) vol 2, p. 533

28. West D X and Palaniandavar M 1983 Inorg. Chim. Acta 7161

29. Thompson L K, Ramaswamy B S and Dawe R D 1978 Can. J. Chem. 561311

30. Bereman R D, Shields G D, Dorfman J R and Bordner J 1983 J. Inorg. Biochem. 1975

31. Adams H, Bailey N A, Rodriguez de Barbarin C O, Fenton D E and He Q-Y 1995 J. Chem. Soc., Dalton Trans. 2323

32. Hathaway B J and Billing D E 1970 Coord. Chem. Rev. 5143

33. Sakaguchi U and Addison A W 1979 J. Chem. Soc., Dalton Trans. 600

34. West D X and Palaniandavar M 1983 Inorg. Chim. Acta 76 L149

35. Knowles P F, Brown R D III, Koenig S H, Wang S, Scott R A, McGuirl M A, Brown D E and Dooley D M 1995 Inorg. Chem. 343895

36. Amundsen A R, Whelan J and Bosnich B 1977 J. Am. Chem. Soc. 996730

37. Adams H, Bailey N A, Fenton D E, He Q-Y, Ohba M and Okawa H 1994 Inorg. Chim. Acta 2151

38. Oberhausen K J, O'brien R J, Richardson J F and Buchanan R M 1990 Inorg. Chim. Acta 173 145

39. Karlin K D, Dahlstorm P L, Hyde J R and Zubieta J 1980 J. Chem. Soc., Chem. Commun. 906

40. Karlin K D, Hayes J C, Juen S, Hutchinson J P and Zubieta J 1982 Inorg. Chem. 214106

41. Whittaker J W 1994 In Metal ions in biological systems (eds) H Sigel and A Sigel (Basel, Switzerland: Marcel Dekker) pp 315-360

42. Whittaker J W In Bioinorganic chemistry of copper (eds) K D Karlin and Z Tyeklar (New York: Chapman \& Hall) pp 447-458

43. Whittaker M M and Whittaker J W 1993 Biophys. J. 64762

44. Whittaker M M, Kersten P J, Nakamura N, Sanders-Loehr J, Schweizer E S and Whittaker J W 1996 J. Biol. Chem. 271681

45. Adams H, Bailey N A, Camphell I K, Fenton D E and He Q-Y 1996 J. Chem. Soc., Dalton Trans. 2233

46. Addison A W 1983 In Copper coordination chemistry: Biochemical and inorganic perspectives (eds) K D Karlin and J Zubieta (Guilderland, New York: Adenine) p 109

47. Chaudhuri P, Hess M, Flörke U and Wieghardt K 1998 Angew. Chem. Int. Ed. 372217

48. Das G, Shukla R, Mandal S, Singh R and Bharadwaj P K 1997 Inorg. Chem. 36323

49. Halcrow M A, Chia L M L, Liu X, McInnes E J L, Yellowlees L J, Mabbs F E and Davies J E 1998 Chem. Commun. 2465

50. Halcrow M A, Chia L M L, Liu X, McInnes E J L, Yellowlees L J, Mabbs F E, Scowen I J, McPartlin M and Davies J E 1999 J. Chem. Soc. Dalton Trans. 1753

51. Wang Y, DuBois J L, Hedman B, Hodgson K and Stack T D P 1998 Science 279537

52. West D X and Palaniandavar M 1983 Inorg. Chim. Acta 77 L97 